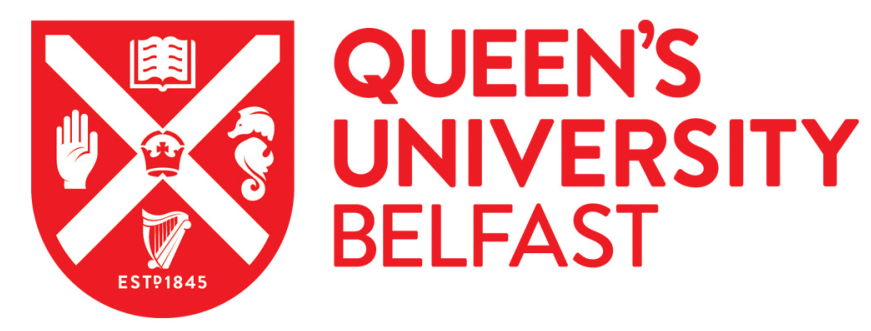

\title{
An interesting case of ptosis in an infant
}

Groves, H. E., Christie, S., McGinnity, G., Hanrahan, D., \& Thompson, A. (2015). An interesting case of ptosis in an infant. Archives of Disease in Childhood: Education and Practice Edition, 100(6), 294. https://doi.org/10.1136/archdischild-2014-307248

Published in:

Archives of Disease in Childhood: Education and Practice Edition

\section{Document Version:}

Early version, also known as pre-print

\section{Queen's University Belfast - Research Portal:}

Link to publication record in Queen's University Belfast Research Portal

\section{Publisher rights}

Copyright 2015 the authors.

This is an open access Creative Commons Attribution-NonCommercial License (https://creativecommons.org/licenses/by-nc/4.0/), which permits use, distribution and reproduction for non-commercial purposes, provided the author and source are cited.

\section{General rights}

Copyright for the publications made accessible via the Queen's University Belfast Research Portal is retained by the author(s) and / or other copyright owners and it is a condition of accessing these publications that users recognise and abide by the legal requirements associated with these rights.

\section{Take down policy}

The Research Portal is Queen's institutional repository that provides access to Queen's research output. Every effort has been made to ensure that content in the Research Portal does not infringe any person's rights, or applicable UK laws. If you discover content in the Research Portal that you believe breaches copyright or violates any law, please contact openaccess@qub.ac.uk. 


\section{Archives of \\ Disease in Childhood}

\section{An Interesting case of ptosis in an infant}

\begin{tabular}{|r|l|}
\hline Journal: & Archives of Disease in Childhood \\
\hline Manuscript ID: & edpract-2014-307248.R2 \\
\hline Article Type: & Epilogue \\
\hline Edition: & not in use \\
\hline Complete List of Authors: & $\begin{array}{l}\text { Groves, Helen; Royal Belfast Hsopital For Sick Children, Paediatrics } \\
\text { Christie, Sharon; Royal Belfast Hospital for Sick Children, Paediatric } \\
\text { Infectious disease Department } \\
\text { McGinnity, Gerry; Royal Victoria Hospital, Ophthalmology } \\
\text { Hanrahan, Donncha; Royal Belfast Hospital for Sick Children, Paediatric } \\
\text { Neurology } \\
\text { Thompson, Andrew; Royal Belfast Hospital for Sick Children, General } \\
\text { Paediatrics }\end{array}$ \\
\hline Keywords: & \begin{tabular}{l} 
Infectious Diseases, Neurology, ptosis, streptococcus pneumoniae \\
\hline
\end{tabular} \\
\hline
\end{tabular}

SCHOLARONE

Manuscripts 


\section{An Interesting case of ptosis in an infant}

A 6-week-old infant presented to accident and emergency with apnoeic episodes. On arrival the infant was pale and floppy, requiring fluid resuscitation and intubation prior to transfer to the paediatric ICU. Broad spectrum intravenous antibiotics were commenced and the infant made a good recovery, being extubated after 48 hours. Lumbar puncture was unsuccessful, however blood cultures were positive for Streptococcus pneumoniae.

By day 4 the infant's left eye was noted to be closed over and ophthalmological assessment revealed a complete ptosis (Figure 1). The pupil was dilated and unreactive to light. The resting position of the left eye was downward and outward with limited ocular movements in the superior and medial directions.

\section{QUESTIONS}

1. Which Cranial nerve is affected?

2. What causes of this condition should be considered in this case?

3. How should this condition be investigated and managed? 


\section{ANSWERS}

1. This is left oculomotor nerve palsy.

The oculomotor nerve innervates the levator palpebrae superioris, ciliary/iris sphincter muscles and all extra-ocular muscles except the lateral rectus (cranial nerve VI innervation) and superior oblique (cranial nerve IV innervation). Therefore, paralysis prevents elevation of the eyelid (ptosis), pupillary dilatation and results in deficient eye adduction, supraduction, and infraduction. The unopposed lateral rectus and superior oblique muscle action causes the affected eye to look downward and outward at rest.

2. Oculomotor nerve palsy is rare in children and is most commonly congenital or developmental in origin. Damage to the Edinger-Westphal/motor nuclei supplying the nerve or to the nerve itself can cause paralysis. Trauma, particularly birth trauma, is a wellrecognised cause of oculomotor nerve palsy in neonates and infants. Disruption to the vasa nervosum can result in palsy and may be caused by arteriovenous malformation, cerebral infarct or cavernous sinus thrombosis. ${ }^{1,2}$ Tumours of the cavernous sinus or thalamus regions may present with oculomotor nerve palsy, as can demyelinating disease or other disorders leading to inflammation along the path of the nerve, although these are unlikely in a 6-week-old infant. ${ }^{1,2}$

Exclusion of meningitis infection is a priority in the context of possible sepsis. Unfortunately CSF cultures were unavailable, however blood cultures grew Streptococcus pneumoniae. Cranial nerve palsies are uncommon in non-tuberculous meningitis but have been reported in S. pnuemoniae meningitis ${ }^{3}$ which is the likely cause of oculomotor nerve palsy in this case.

3. The finding of a uni-lateral, dilated non-reactive pupil in an ill patient may indicate compression of the oculomotor nerve by temporal lobe (uncal) herniation secondary to raised intracranial pressure (particularly if reduced consciousness). Urgent neuro-imaging is the investigation of choice, although it should be noted that herniation is extremely rare in the presence of an open anterior fontanelle.

Exclusion of intracranial abnormality or vascular causes, especially cavernous sinus thrombosis, should be performed using MRI/MRA brain. ${ }^{4,5}$

Careful history and examination should direct further investigation with early paediatric ophthalmology and neurology input. Lumbar puncture investigation (unless contraindicated) is indicated if signs of meningeal irritation exist to exclude bacterial/TB meningitis. Metabolic investigations should also be performed (normal for this infant).

The underlying cause should be identified and treated were possible. The integrity of the eye is maintained by conservative management while awaiting spontaneous recovery, i.e. regular eye drops and taping the eye closed. In the absence of spontaneous recovery, ophthalmic surgical management of the ptosis may be required. 


\section{PATIENT OUTCOME}

In this case MRI/MRA brain imaging showed no infarction and only mild angiopathic changes around the internal carotid bifurcation bilaterally, in keeping with meningitis. The infant's oculomotor palsy was therefore felt to be secondary to $\mathrm{S}$. pnuemoniae meningitis.

The infant completed 14 days of IV antibiotics and was discharged from hospital. The ptosis gradually improved over the ensuing months with complete resolution of all abnormal ophthalmological signs by 6 months of age.

\section{REFERENCES}

1. Inoue N, Watanabe HR, Okamura K, Sakaki M, Kage T, Nagahiro S, Kagami S. Atypical teratoid rhabdoid tumor in the cavernous sinus of a toddler presenting with oculomotor nerve palsy. Childs Nerv Syst 2014; DOI 10.1007/s00381-014-2407-6.

2. Ng YSP, Lyons C. Oculomotor nerve palsy in childhood. Can J Ophthalmol 2005; 40(5): 645653.

3. Chu ML, Litman N, Kaufman DM, Shinnar S. Cranial nerve palsies in Streptococcus pneumonia meningitis. Pediatric Neurology 1990; 6(3): 209-210.

4. Yanovitch T, Buckley E. Diagnosis and management of third nerve palsy. Current Opinion in Ophthalmology 2007; 18(5): 373-378.

5. Marais W, Barrett $\mathrm{S}$. An overview of the third, fourth and sixth cranial nerve palsies. CME 2013; 31(4): 147-152. 


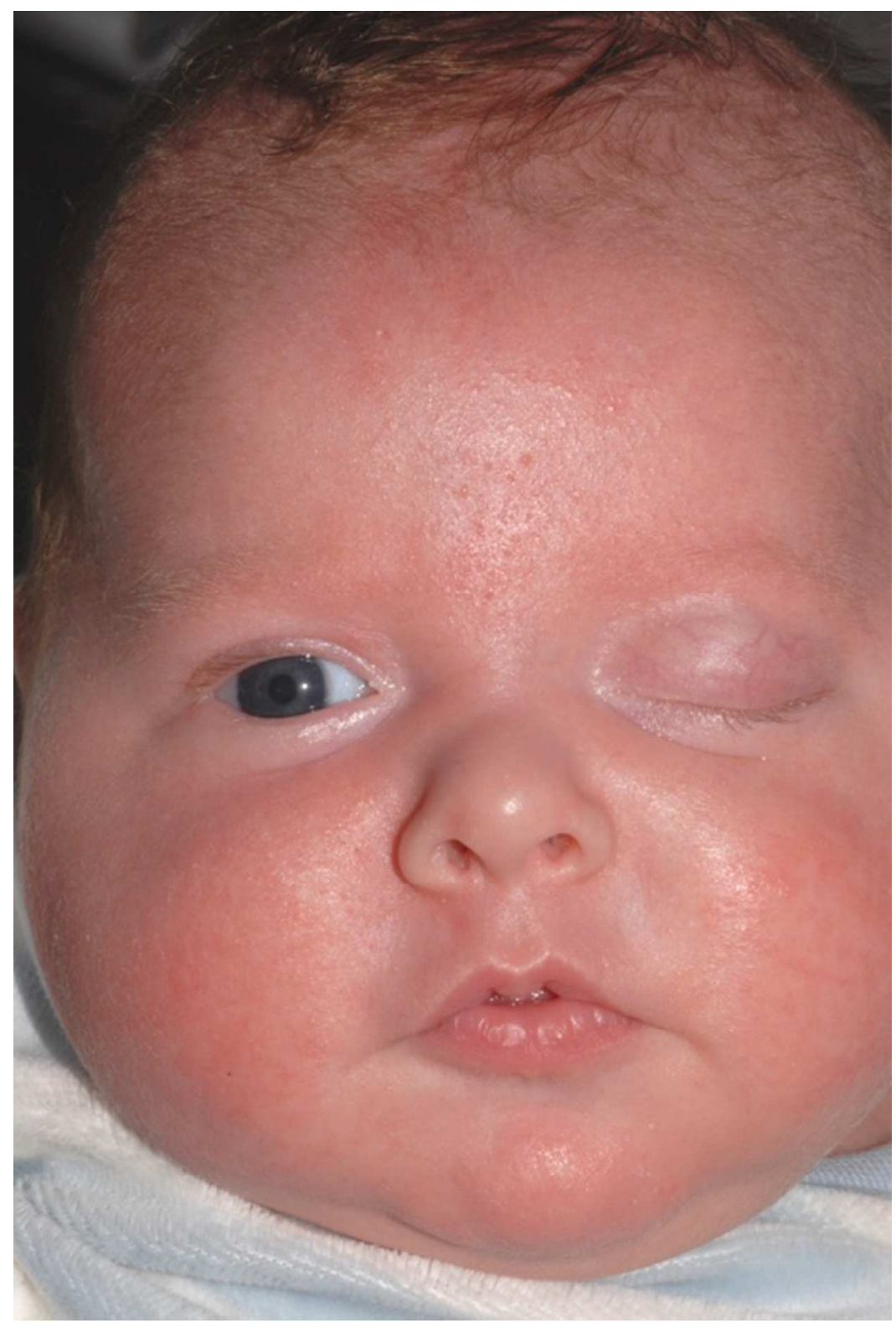

$59 \times 88 \mathrm{~mm}(220 \times 220 \mathrm{DPI})$ 